\title{
UTRINKI Z OBISKA INŠTITUTA ZA VSEŽIVLJENJSKO UČENJE UNIVERZE $\checkmark$ LEICESTRU IN OB EVROPSKEM PROJEKTU/MREŽI FORAGE
}

Zaradi projekta FORAGE me je pot po tanki, povsem nepričakovani plasti snega pripeljala tudi na Inštitut za vseživljenjsko učenje na Univerzi $v$ Leicestru, kjer sem se zadržala od 8. do 10. februarja. Četudi kdo ne bi vedel, da je Leicester univerzitetno mesto in sedež slovite organizacije za izobraževanje odraslih NIACE, bi kaj kmalu spoznal, da ga tam obkrožajo številni študenti, pa tudi številni plakati; marketinška poteza, kakršnih v Sloveniji (̌se) nismo vajeni. Zavajajoči plakati po domala vseh pomembnejših ulicah prišleku povedo, da je bila Univerza v Leicesteru prejšnje leto razglašena za najboljšo univerzo $\mathrm{v}$ Veliki Britaniji, pa tudi, da se uvršča »med dva odstotka najboljših univerz na svetu «. Zapis naredi iz znanja in kulture blago kot vsako drugo. Zapis zapeljuje in vara; nepozorni mimoidoči lahko meni nič, tebi nič razumejo sporočilo drugače: da gre za drugo najboljšo univerzo na svetu. In zakaj je ta univerza cenjena? Ker ima urejene procese zagotavljanja kakovosti, dobro zapisane in dokumentirane procese, ker veliko študentov, ki študij začne, tega tudi konča, ker se na univerzi trudijo, da vključujejo študente iz kulturno in socialno deprivilegiranih okolij. Ker je v študentskem naselju tudi monumentalno grajen, prelep študentski center, prostor srečevanja študentov, a tam najdemo tudi restavracije in trgovine, ki študente navajajo na porabo in tudi živijo od njihove porabe (SPAR, Starbucks, papirnice, kavarnice). Vse te ugodnosti name niso naredile posebnega vtisa; porabniška kultura prodira $\mathrm{v}$ vse pore našega življenja, tudi tja, kjer nekoč ni imela prostora. Razveselilo pa me je dejstvo, da center upravljajo študenti sami ... To je zanje vredna izkušnja, s katero gredo lahko na pot $\mathrm{v}$ življenje.

\section{DOLGA IN POPISANA TRADICIJA IZOBRAŽEVANJA ODRASLIH}

Univerza v Leicestru ima dolgo tradicijo izobraževanja odraslih. Že leta 1852 so v Leicestru ustanovili prvi univerzitetni kolidž. Da je bil to kolidž za vse ljudi vseh starosti, o tem ni dvomiti. Tam so že takrat delali »izdelke starega izobraževalnega sistema«, kot je sam sebe predstavil naš predavatelj prof. John Gibson, ki zase pravi: »Ime mi je John, sem vseživljenjski učenec.«Vendar je bilo njegovo formalno izobraževanje na Univerzi v Leicestru obrnjeno v preteklost. Ali je to dobro ali ne, o tem se zdaj krešejo mnenja v Evropi.

V 18. stoletju so v Angliji poznali skupnostne vasi (angl. community villages), kjer se je bilo mogoče izobraževati, v 19. stoletju pa delavske knjižnice (angl. workers' subscription libraries), kamor so se lahko, oh, čudo, vpisale tudi ženske. Z njimi povezani so inštituti mehanikov (angl. mechanics' institutes), kjer je potekalo obvezno izobraževanje za družine, poleg znanja pa so jim nudili tudi hrano in zavetje. V 20. stoletju pa so v Angliji dobili centre za učenje 
odraslih (angl. adult learning centres), kjer se je mogoče učiti temeljnih spretnosti in obiskovati kratke, zvečine večerne tečaje. Izobraževanje odraslih je bilo tako velikokrat imenovano kar večerno izobraževanje (angl. evening classes).

Tradicionalno izobraževanje odraslih v Angliji in Walesu je temeljilo na prepričanju, »da živimo, se učimo, delamo in se igramo skupaj z drugimi in da se polno razvijamo le v družbi in družbenih skupinah znotraj lokalne skupnosti. Nekatere takšne skupine so pravzaprav izobraževalni organizmi, številne takšne skupine so zajete $\mathrm{v}$ izobraževalnih ustanovah, druge spet so povsem drugačne in imajo drugačne izobraževalne potrebe. Celotna lokalna skupnost je na več načinov edinstvena in celovita; ima celično strukturo, pri čemer je vsakdo od časa do časa subjekt, ki ima različne osebne potrebe, in je hkrati socialni subjekt ter tako član družbe, vse to pa na različne načine in sredi raznolikih ter med seboj prepletenih struktur.«(Jennings, 1980: 11.)

\section{SAMOORGANIZIRANO UČENJE DOŽIVLJA RAZCVET}

Samoorganizirano učenje se v Veliki Britaniji množično širi in država takšno izobraževanje podpira. Razumjivo. Tudi v Sloveniji čutimo in vemo, da so potrebe po znanju tako velike, da ni dovolj šolskih zgradb, učiteljev, da ni dovolj denarja, da bi jih lahko zadovoljili. Zakaj ne bi izkoristili znanja, ki ga že imamo, zakaj ga ne bi izmenjali v recipročnem učenju, zakaj ne bi skupaj gradili novega v samoorganiziranih oblikah učenja in izobraževanja? ${ }^{1}$ Še več, leta 2010 je bil v Veliki Britaniji sprejet tudi Zakon o enakosti (angl. Equality Act), ki širi možnosti za odrasle, da se vključijo v izobraževanje. Pod vplivom tega zakona sta se močno razmahnila tako izobraževanje odraslih kakor tudi skupnostno izobraževanje. $\mathrm{V}$ izobraževanje so se kmalu začeli vključevati tudi starejši odrasli. K izobraževanju starejših Britance navajajo prebivalstvene spremembe, potrebe trga, prepričanje, da ima sleherno učenje in izobraževanje širše dobrodejne učinke hkrati na posameznika in skupnost. $\mathrm{Na}$ izobraževanje starejših odraslih navaja tudi potreba starejših, da živijo zdravo in se dobro počutijo. ${ }^{2}$ Če britanske razloge za razvoj izobraževanja starejših primerjamo s slovenskimi, spoznamo, da v Veliki Britaniji dosti bolj izhajajo iz trenutnih družbenih in ekonomskih razmer. V Sloveniji pa smo že leta 1984 izhajali iz širših humanističnih postulatov, iz pravice, ki smo jo želeli uresničiti, da postane človekovo življenje krog, da tega kroga ne prekinjamo (denimo z upokojitvijo), da ustvarimo okoliščine, kjer se bo socialno in delovno življenje z izobraževanjem po upokojitvi lahko nadaljevalo. Izhajali smo iz tega, da imajo starejši pravico sodelovati v ekonomskem in družbenem življenju in da zato starejši odrasli potrebujejo izobraževanje, tako kot vse druge generacije. Izhajali pa smo tudi iz tega, da je treba okolja, ki pripadajo mladim in srednje starim, povezati z okolji starejših. O zdravem staranju so že v tistih časih razmišljali tudi v Gerontološkem društvu Slovenije, v društvih upokojencev in še kje (Vovk, 1995; Hojnik-Zupanc, 1997; Findeisen, 2010).

Starejši Britanci naj bi danes vzdrževali duševno, telesno in socialno ravnovesje, tj. zdravje, tudi ob pomoči izobraževanja. V vaseh in manjših krajih obstajajo po vzoru tradicionalnega National Trusta, ki omogoča, da starejši skrbijo za kulturno dediščino, delajo v muzejih in galerijah, tudi učni skladi skupnostnega učenja odraslih (angl. adult community learning trusts). ${ }^{3} \mathrm{Na}$ izobraževanje odraslih vplivajo tudi evropski okvirni programi, kot so Erasmus za vse, Grundtvig in podobni. Še 
misel mimogrede: potruditi bi se morali in skupaj s svojimi nacionalnimi agencijami za evropske programe pripraviti razpise, ki bodo pisani na kožo izobraževalnim organizacijam ter seveda tudi nacionalnim in evropskim družbenim ciljem. Angleži te priložnosti ne spustijo iz rok.

\section{KAJ JE IN ZAKAJ JE FORAGE}

FORAGE (angl. for age ali four-age) je ime, ki so ga koordinatorji projekta na LLI (Inštitut za vseživljenjsko učenje na Univerzi v Leicestru) dali nastajajoči mreži mrež na področju izobraževanja starejših odraslih. Pravijo, da je to mreža izjemno izobraženih in izkušenih predstavnikov na področju razvijajočega se izobraževanja starejših odraslih iz 20 držav, zato naj bi bili tudi delo, dejavnosti, vsebine, cilji, smotri, ki smo jih zastavili v FORAGE, zelo ambiciozni. Že prva naša naloga je tako prinesla bogat vir informacij o izobraževanju starejših v Evropi, četudi nismo načrtovali, da bo tako. Izobraževanje starejših odraslih je namreč razmeroma slabo dokumentirano, čeprav ga zdaj srečamo v mnogih evropskih državah, res pa je, da smo bili v Sloveniji med prvimi ter da imamo na tem področju izjemno in mednarodno priznano tradicijo.

Uvodni vprašalnik, ki so ga pripravili koordinatorji (Jim Soulsby s sodelavci), se je nanašal na preteklo delo, izkušnje, dosežke, raziskovalna področja, težave in pričakovanja udeleženih v projektu na področju izobraževanja starejših odraslih. Ker so udeleženci v projektu hkrati med glavnimi akterji na tem področju, so se njihova pričevanja izkazala za zelo pomembna. $Z$ njimi smo pridobili prvi vpogled v izobraževanje starejših odraslih po Evropi. Še več, vprašalnik je razkril tudi načela in vrednote, ki urejajo izobraževanje starejših odraslih ter določanje vsebin in ciljev tega izobraževanja $\mathrm{v}$ posameznih državah in okoljih. Izobraževanje starejših odraslih je tako lahko vse od izobraževanja za prosti čas, izboljševanje in vzdrževanje zaposljivosti pri starejših delavcih - nasprotno od mlajših zaposlenih se ti navadno ne izobražujejo za to, da bi vzdržali kompetitivne odnose v podjetju, da bi ohranili delovno mesto, marveč predvsem za to, da bi bili sprejeti, spoštovani, vpeti v odnose v podjetju - izobraževanja za osebnostno rast, zdravo življenje, plačano in prostovoljsko delo, dejavno državljanstvo, obvladovanje situacij vsakdanjega življenja ... pa vse do medgeneracijskega izobraževanja in izobraževanja za kolektivno osvobajanje starejših ob pomoči izobraževanja, ki naj pripelje do večje enakosti in družbene pravičnosti. Zdi pa se, da so zdaj vsepovsod v Evropi prepoznali širše dobrodejne učinke učenja starejših odraslih, njegove hkratne učinke tako na posameznika kakor tudi na skupnost. Nikjer več ne vlada prepričanje, da se starejši učijo kar tako, »da se zamotijo, ker nekaj pač morajo početi $\ll$.

\section{CILJI IN SMOTRI NASTAJAJOČE MREŽE FORAGE}

Napisati projekt na papirju je nekaj, odločiti se za najpomembnejše cilje in dejavnosti pa je že nova stopnja v njegovem razvoju, tako tudi v FORAGE. Mreža si je zastavila za svojo nalogo, da bo ustvarila bazo podatkov o že opravljenih raziskavah in uvedenih političnih rešitvah. Baza bo namenjena splošni javnosti, strokovnjakom, predvsem pa raziskovalcem in ustvarjalcem lokalnih in državnih ter evropskih politik. Mreža bo vzpostavila spletno stran in interaktivni portal, kamor bo mogoče sproti zapisovati primere dobre prakse in druge nove podatke. Ker v projektu sodeluje tudi britansko Društvo za izobraževanje in staranje, ki zdaj izdaja tudi znanstveno 